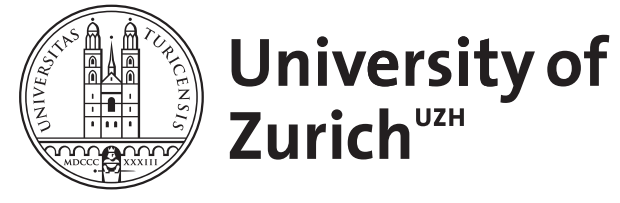

\title{
Rebuttal to the pro statement
}

Jacobs, Robert A

DOI: https://doi.org/10.1089/ham.2013.1076

Posted at the Zurich Open Repository and Archive, University of Zurich ZORA URL: https://doi.org/10.5167/uzh-90888

Journal Article

Published Version

Originally published at:

Jacobs, Robert A (2013). Rebuttal to the pro statement. High Altitude Medicine Biology, 14(4):333.

DOI: https://doi.org/10.1089/ham.2013.1076 


\title{
Rebuttal to the Pro Statement
}

\author{
Robert A. Jacobs ${ }^{1-3}$
}

$\mathbf{T}$

HE EFFICACY OF ALTITUDE TRAINING (living high-training high; LHTH) was originally contested because, as appropriately stated in the introduction of the seminal "live high-train low" (LHTL) study, "when appropriate control groups have been included, living and training at altitude have not been proven to be advantageous compared with equivalent training at sea level" (Levine and Stray-Gundersen, 1997). Evaluating the efficacy of the LHTL model is no different. When appropriate (live low-train low; LLTL) control groups are included, does living and training at altitude prove to be advantageous over the equivalent living and training at sea level? Hitherto there is principally one such (nonblinded) study that supports LHTL over LLTL (Levine and Stray-Gundersen, 1997). Alternatively, there are numerous studies that repeatedly fail to demonstrate an improvement in sea-level performance following LHTL when compared to equivalent LLTL, as stated in my original position (Jacobs, 2013). Many of these studies have been inappropriately referenced in support of the LHTL model (Wilber, 2013): 1) Maximal aerobic power $\left(\mathrm{Vo}_{2 \max }\right)$ and volume of oxygen consumed $\left(\mathrm{Vo}_{2}\right)$ in a 2 minute all-out effort actually diminished significantly in the LHTL group, while the corresponding LLTL values were unchanged. However, there were no differences between groups and the corresponding work output did not changed for either group (Gore et al., 2001); 2) While $\mathrm{Vo}_{2 \max }$ improved in the LHTL group, "no statistical difference was observed between the two groups during the study" (Brugniaux et al., $2006)$; 3) The $2.0 \%$ increase in maximal speed achieved during a maximal anaerobic running test in LHTL subjects "did not differ significantly from the $1.4 \%$ increase" observed in the LLTL group (Nummela and Rusko, 2000); 4) $\mathrm{VO}_{2 \max }$ increased in the LHTL and LLTL groups "to the same extent" (Schmitt et al., 2006); 5) Following two separate LHTL blocks, when "compared with the (LLTL) group, the LHTL group was substantially faster (in a $4.5 \mathrm{~km}$ running time trial) after block 1 but possibly slower after block 2", and there were no significant differences in the change in mean $\mathrm{VO}_{2 \max }$ or running velocity at $\mathrm{VO}_{2 \max }$ (Robertson et al., 2010); and 6) The ratio of maximal mean power output obtained during a 30 minute cycle ergometer test to that of a 4 minute test "decreased for (LHTL) $(76 \pm 2 \%)$ after sleeping at altitude but improved for (LLTL) (82 $\pm 4 \%$ ) after normal training" (Martin et al., 2002). There is undeniable and overwhelming evidence refuting the efficacy of LHTL.

\section{Author Disclosure Statement}

No competing financial interests exist.

\section{References}

Brugniaux JV, Schmitt L, Robach P, et al. (2006). Eighteen days of "living high, training low" stimulate erythropoiesis and enhance aerobic performance in elite middle-distance runners. J Appl Physiol 100:203-211.

Gore CJ, Hahn AG, Aughey RJ, et al. (2001). Live high:train low increases muscle buffer capacity and submaximal cycling efficiency. Acta Physiol Scand 173:275-286.

Jacobs RA. (2013). Live high-train low does not improve sealevel performance beyond that achieved with the equivalent living and training at sea-level. High Alt Med Biol 14:328-330.

Levine BD, and Stray-Gundersen J. (1997). “Living high-training low": Effect of moderate-altitude acclimatization with lowaltitude training on performance. J Appl Physiol 83:102-112.

Martin DT, Hahn AG, Lee H, Roberts AD, Victor J, and Gore CJ. (2002). Effects of a 12-day "live high, train low" cycling camp on 4-min and 30-min performance. Med Sci Sports 34:S274.

Nummela A, and Rusko H. (2000). Acclimatization to altitude and normoxic training improve $400-\mathrm{m}$ running performance at sea level. J Sports Sci 18:411-419.

Robertson EY, Saunders PU, Pyne DB, Aughey RJ, Anson JM, and Gore CJ. (2010). Reproducibility of performance changes to simulated live high/train low altitude. Med Sci Sports Exerc 42:394-401.

Schmitt L, Millet G, Robach P, Nicolet G, Brugniaux JV, Fouillot JP, and Richalet JP. (2006). Influence of "living high-training low" on aerobic performance and economy of work in elite athletes. Eur J Appl Physiol 97:627-636.

Wilber RL. (2013). Live high + train low does improve sea level performance. High Alt Med Biol 14:325-327.

Address correspondence to: Robert A. Jacobs Institute of Physiology and Zurich Center for Integrative Human Physiology (ZIHP)

Winterthurerstrasse 190

CH-8057 Zurich

Switzerland

E-mail: jacobs@vetphys.uzh.ch

Received July 13, 2013; accepted in final form July 20, 2013.

\footnotetext{
${ }^{1}$ Zurich Center for Integrative Human Physiology (ZIHP); ${ }^{2}$ Institute of Physiology, and ${ }^{3}$ Institute of Veterinary Physiology, Vetsuisse Faculty, University of Zurich, Zurich, Switzerland.
} 